\title{
Associations between environmental factors and incidence of cutaneous melanoma. Review
}

\author{
Katarina Volkovova ${ }^{1 *}{ }^{*}$, Dagmar Bilanicova ${ }^{1,2 \dagger}$, Alena Bartonova ${ }^{3 \dagger}$, Silvia Letašiová ${ }^{4}$, Maria Dusinska ${ }^{1,3 \dagger}$ \\ From HENVINET (Health and Environment Network) final conference \\ Brussels, Belgium. 14 April 2010 - 15 April 2010
}

\begin{abstract}
Background: Cutaneous melanoma is one of the most serious skin cancers. It is caused by neural crest-derived melanocytes - pigmented cells normally present in the epidermis and, sometimes, in the dermis.

Methods: We performed a review of current knowledge on the risk factors of cutaneous melanoma. Relevant studies were identified using the PubMed, Science Direct, Medline, Scopus, Scholar Google and ISI Web of Knowledge databases.

Results: Melanoma incurs a considerable public health burden owing to the worldwide dramatic rise in incidence since the mid-1960s. Ultraviolet radiation exposure is the predominant environmental risk factor. The role of geographical (latitude) and individual factors such as skin type, life style, vitamin D levels and antioxidant protection, sunburn, and exposure to other environmental factors possibly contributing to melanoma risk (such as cosmetics including sunscreen, photosensitising drugs, and exogenous hormones) are reviewed in this article. Recently, both rare high risk susceptibility genes and common polymorphic genes contributing to melanoma risk have been identified.

Conclusions: Cutaneous melanoma is a complex cancer with heterogeneous aetiology that continues to increase in incidence. Introduction of new biomarkers may help to elucidate the mechanism of pathogenesis and individual susceptibility to the disease, and make both prevention and treatment more effective.
\end{abstract}

\section{Background}

Cutaneous melanoma is one of the most serious skin cancers. It is caused by neural crest-derived melanocytes pigmented cells normally presented norma in the epidermis and, sometimes, in the dermis [1]. Incidence of melanoma is increasing. While in US the lifetime risk of melanoma in 1935 was one in 1500 persons, in 1960 it was one in 600 persons, and in 2000 it was one in 75 persons [2]. The progression of the melanocyte to a malignant melanoma involves various sequential steps: development of benign naevocellular naevus preneoplastic dysplastic naevus primary melanoma and metastatic melanoma [3]. There are four main types of cutaneous malignant melanoma [4,5]: a) Superficial spreading malignant melanoma

\footnotetext{
* Correspondence: katarina.volkovova@szu.sk

+ Contributed equally

'Slovak Medical University, Bratislava, Slovakia

Full list of author information is available at the end of the article
}

which is the most common among Caucasians and accounts for 70 percent of all melanomas. It usually occurs in adults and may develop anywhere on the body but appears with increased frequency on the upper back of both men and women and on the legs of women; b) Nodular melanoma (accounting for 15 to 30 percent of all melanomas), a dome-shaped, pedunculated or nodular lesion that may occur anywhere on the body. It is commonly dark brown or reddish brown but may occasionally be amelanotic. Nodular melanomas tend to rapidly invade the dermis from the onset with no apparent horizontal growth phase. These tumors are frequently misdiagnosed, because they may resemble blood blisters, hemangiomas, dermal nevi or polypi; c) Lentigo maligna melanoma (which accounts for 4 to 10 percent of all melanomas) originates from lentigo maligna. Untreated lentigo maligna tends to exhibit horizontal or radial growth with epidermal involvement for many years (often decades) before it 
enters the vertical growth phase and invades the dermis to become lentigo maligna melanoma. This change is often indicated clinically by the development of focal papular or nodular areas; d) Acral lentiginous melanoma (2 to 8 percent of all melanomas) occurs on the palmar and plantar surfaces, the digits and the subungual areas.

Although the prognosis of thin melanoma is relatively good, prognosis decreases with increased thickness of the lesions. The diminished prognosis is mainly due to the well established tendency of melanoma to metastasize, which accounts for 75 percent of all deaths associated with skin cancer. In addition, melanomas are highly resistant to most forms of chemotherapy and radiation; therefore, cure of the disseminated disease is uncommon [6]. In women, melanoma often develops in the extremities, most commonly the lower limbs. In men, melanoma is most often found on the trunk, on the area between the shoulders and hips. In both sexes, melanoma can appear on the palms or soles and under the fingernails or toenails [7].

\section{Methods}

An extensive literature search was performed to review current knowledge on cutaneous melanoma including epidemiological studies addressing risk factors of cutaneous melanoma between 1998 and 2010. Relevant studies were identified using the PubMed, Science Direct, Medline, Scopus, Scholar Google and ISI Web of Knowledge databases.

\section{Results - Melanoma risk factors Sunlight exposure}

Sun exposure plays a primary and supporting role in most melanoma tumors. There is evidence that for the four main cutaneous types of melanomas, the pattern of excess sunlight exposure which is most damaging varies $[8,9,5]$. The environmental human carcinogen present in sunlight is ultraviolet (UV) irradiation [10]. The sun emits UVA $(\lambda=320-400 \mathrm{~nm})$, UVB $(\lambda=280-320 \mathrm{~nm})$, and UVC $(\lambda=200-280 \mathrm{~nm})$ ultraviolet radiation. While UVC radiation is ecologically not relevant since it is absorbed by oxygen and ozone in the Earth's atmosphere, the longer wavelength UV-B (280-315 nm) and UV-A (315$400 \mathrm{~nm}$ ) radiation have significant effects on the biota. 98.7\% of the ultraviolet radiation that reaches the Earth's surface is UVA $[11,12]$. The molecular mechanisms by which UV radiation exerts its varied effects are not fully understood; however, it is thought that UV irradiation plays a critical role in melanoma formation [1]. Currently, it is thought that the DNA damaging, carcinogenic, inflammatory, and immunosuppressive properties of UVR all contribute to initiation, progression, and metastasis of primary melanoma [13]. Reactive oxygen species (ROS) overproduction may stimulate malignant transformation to melanoma. Changes in ROS signalling pathways play also important role in the damaging action of UVA and UVB irradiation on the skin [14].

\section{Natural photoprotection}

The term photoprotection designates the mechanisms that nature has developed to minimize the damage that the human body suffers when exposed to UV-irradiation. This damage mostly occurs on the skin, but other parts of the body (especially the testicles) can be affected by UV-light. Photoprotection of the human skin is achieved by the extremely efficient internal conversion of molecules which originally absorb the UV-photon - endogenous chromophores: DNA nucleotides, urocanic acid, proteins, amino acids, melanin and their precursors and metabolites [15]. Internal conversion is a photochemical process that converts the energy of the UV-photon into small amounts of heat. These small amounts of heat are harmless. The energy of the UV-photon not transformed into heat leads to the generation of various harmful reactive chemical species (e.g. singlet oxygen or hydroxyl radical) [16,17].

In DNA this photoprotective mechanism evolved four billion years ago. The purpose of this extremely efficient photoprotective mechanism is to prevent direct and partially indirect DNA damage. The ultrafast internal conversion of DNA reduces the lifetime of DNA in the excited state to only a few femtoseconds $\left(10^{-15} \mathrm{~s}\right)$ - in this way the excited DNA does not have enough time to react with other molecules $[18,19,17]$. The absorption spectrum of DNA shows strong absorption for UVB-radiation and much lower absorption for UVA-radiation (Fig. 1).

It is thought that photoprotection of melanin developed later in the course of evolution. There are two types of skin melanin: eumelanin, a black-brown pigment which is insoluble and is found in brown/black hair and brown eyes, pheomelanin, reddish pigment which is alkali-soluble and is found in red hair and red feathers [20]. All healthy individuals have varying degrees of eumelanin in their skin, while pheomelanin is present only in individuals who carry the corresponding genetic trait. It is thought that eumelanin protection against nutrient photolysis and, specifically, photolysis of folate (owing to the direct connection between folate and reproductive success), was a prime selective inducer which resulted in deeply pigmented skins among people living under high UVB radiation throughout most of the year. The importance of increased eumelanin production to prevent future direct and indirect DNA damage, individual fitness of protection of sweat glands and maintenance of thermoregulatory capability is also thought to have contributed to increased melanization [21]. Eumelanin dissipates more than $99.9 \%$ of the absorbed UV radiation as heat. This means that less than $0.1 \%$ of the excited melanin molecules will undergo harmful chemical reactions or produce free radicals [22]. 


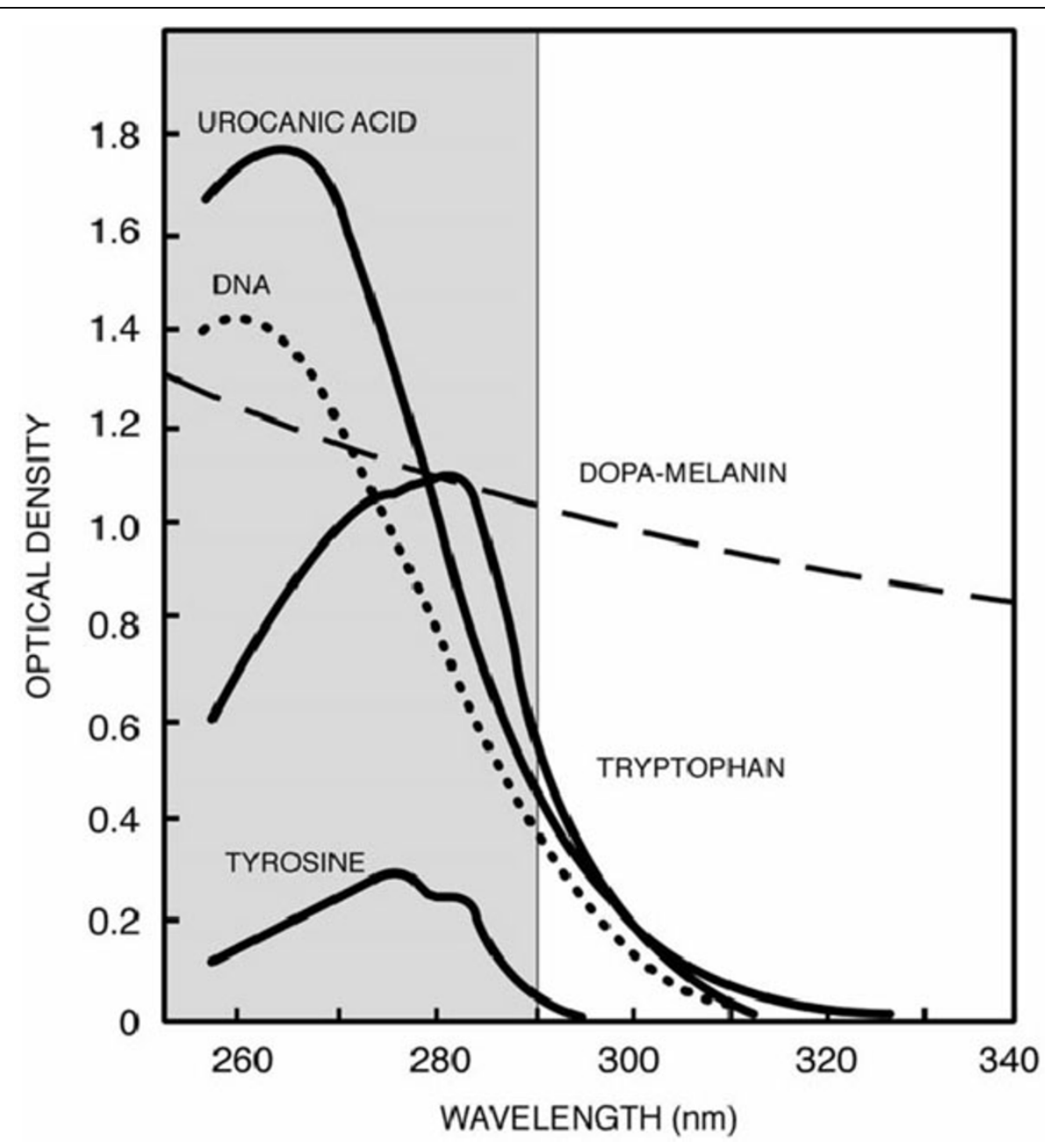

Figure 1 UVR absorption spectra of molecules important to UV-induced health effects DOPA-melanin-synthetic model of eumelanin $(J$ Longstreth et al, 1998)

\section{DNA damage}

The predominant component of sunlight, UVA, penetrates fivefold deeper into skin than UVB due to its longer wavelengths $[23,24]$. Whereas UVA can indirectly damage DNA through the formation of reactive oxygen radicals, UVB can directly damage DNA causing apoptosis of keratinocytes by forming sunburn cells [25]. It has been shown that $92 \%$ of all melanoma are caused by indirect DNA damage and that only $8 \%$ of all melanoma are caused by direct DNA damage [26].

\section{Direct DNA damage and sunburn}

Since the action spectrum of sunburn is identical to the absorption spectrum of DNA, it is generally accepted that direct DNA damage is the cause of sunburn [27]. It can occur when DNA directly absorbs UVB photons. UVB light causes the formation of covalent linkages between pairs of thymine and cytosine bases in DNA and forms pyrimidine dimers (cyclobutane dimer). The radiation excites DNA molecules in skin cells, causing aberrant covalent bonds between adjacent cytosine bases by producing a dimer. During DNA replication, DNA polymerase incorporates an incorrect base opposite to an aberrant base, causing a mutation. The mutation caused by direct DNA damage can lead to skin cancers. The second most frequent UV photoproducts are 6-4 photoproducts (6-4 PPs), which are pyrimidine adducts and their Dewar valence isomers formed by the photo isomerisation of 6-4 PPs by wavelengths longer than 290nm [28-33]. These reactions are quite common: each cell in the skin might experience 50-100 reactions during every second of sunlight exposure. Most of these genetic lesions are corrected by the mechanism of nucleotide excision repair. If the damage remains uncorrected, the genetic information may be permanently mutated. 


\section{Indirect DNA damage and melanoma}

Malignant melanoma is mainly caused by indirect DNA damage. A limited number of molecules in tissue weakly absorb UVA irradiation. After UVA irradiation absorption, these molecules (endogenous photosensitizers) converts to their long-lived triplet state that allows the transfer of energy to oxygen molecules. The transferred energy leads to an energetically excited oxygen molecule (singlet oxygen), which is highly reactive. Some of the endogenous photosensitizers have been identified, for example, flavins [34], NADH/NADPH [35], urocanic acid [36], and some sterols [37]. 3-hydroxypyridine derivatives comprising a wide range of skin biomolecules, such as enzymatic collagen cross-links, B6 vitamin, and likely advanced glycation end products in chronologically aged skin, constitute a novel class of UVA photosensitizers, capable of skin photooxidative damage [38]. Wenczl et al. [39] demonstrated that UVA-irradiated cultured human melanocytes are photosensitized also by chromophores as pheomelanin and/or melanin intermediates. UVB natural chromophores may also exhibit similar phototoxic properties. Babu and Joshi [40] suggested that UVB-sensitized tryptophan produces singlet oxygen $\left({ }^{1} \mathrm{O}_{2}\right)$ and superoxide radicals $\left(\mathrm{O}_{2}{ }^{-}\right)$, and these reactive forms of oxygen may contribute to membrane-, cytoplasm- and DNA-damaging effects.

Singlet oxygen, hydroxyl radical and hydrogen peroxide are reactive oxygen species (ROS) considered to be most responsible for producing oxidative stress in cells and organisms [41]. Oxidative stress is caused by imbalance between ROS production and a biological system's ability to readily detoxify these reactive intermediates or easily repair the resulting damage. Thus, oxidative stress is accepted as a critical pathophysiological mechanism in cancererogenesis [42]. Reactive chemical species can reach DNA by diffusion and the bimolecular reaction will damage the DNA [43]. Singlet oxygen interacts preferentially with guanine to produce 8-oxo-7,8-dihydroguanine (formed by the loss of two electrons). Further removal of two electrons from this product can yield spiroiminodihydantoin ( $\mathrm{Sp}$ ) R and S stereoisomers. Both in vitro and in vivo experiments have shown that the Sp stereoisomers are highly mutagenic, causing $\mathrm{G} \rightarrow \mathrm{T}$ and $\mathrm{G} \rightarrow>$ $\mathrm{C}$ conversions. Hence, they are of interest as examples of endogenous DNA damage that may initiate cancer $[41,44]$.

\section{Ozone depletion and skin cancer}

The radical increase of melanoma that has occurred in the last years has been associated with ozone depletion caused by ozone depleting substances (ODS) of anthropogenic origin, resulting in higher UVB radiation reaching the ground. Decreases in ozone have generated worldwide concern leading to adoption of the Montreal
Protocol banning the production of ODS such as chlorofluorocarbon (CFC), other fully halogenated CFCs (freons), carbon tetrachloride, hydrochlorofluorocarbons, hydrobromofluorocarbons, methylchloroform, important industrial substances like halons (bromofluorocarbon compounds) and methyl bromide. Ozone depleting substances were used in automobile and truck air conditioning units, domestic and commercial refrigeration and air conditioning/heat pump equipment, aerosol products, portable fire extinguishers, insulation boards, panel and pipe covers and pre-polymers (The Montreal Protocol on Substances that Deplete the Ozone Layer, 2000). The level of UVB in sunlight is a strong function of latitude, whereas UVA is not. It is not surprising that the ratio of non-melanoma skin cancer incidence in Australia/Norway is an order of magnitude higher than for cutaneous malignant melanoma [45]. Based on studies which have found that $92 \%$ of all melanoma are caused by indirect DNA damage from UVA [46], we assume that other main hazard factors (pigmentary traits, ethnic origin, benign nevi, or family history) and not ozone depletion are responsible for radical increase of melanoma last years.

\section{Sunburn and sunscreens}

An increased risk of melanoma was seen with increasing number of sunburns for all ages, not just childhood. The magnitude of risk for five sunburns per decade was shown to be highest for adult and lifetime sunburns [47].

Although sunscreens prevent sunburn [48-50], epidemiological or laboratory evidence that they prevent melanoma in humans is still missing.

Sunscreens have traditionally been divided into organic (chemical) absorbers and inorganic (physical) blockers on the basis of their mechanism of action. The organic compounds absorb high- intensity UV rays with their excitation to a higher energy state. Excess energy is dissipated by emission at longer wavelengths or relaxation by photochemical process such as isomerization and heat release. These organic compounds include para-aminobenzoic acid (PABA) and PABA esters, salicylates, cinnamates, benzophenons, butyl methoxydibenzoylmethane (Parsol 1789), drometrizole trisulphonic (Mexoryl XL), terephthalydene dicamphor sulphonic acid (Mexoryl SX), methylene bisbenzotriazol tetramethylbutylphenol (tinasorb $\mathrm{M}$ ) and anisotriazine (Tinasorb S).

The inorganic agents, which protect the skin by reflecting and scattering UV, are nanoforms of titanium dioxide $\left(\mathrm{TiO}_{2}\right)$ and zinc oxide $(\mathrm{ZnO})$. These sunscreens are very efficient, photostable and offer protection extending into the UVA and visible range of the electromagnetic spectrum with almost negligible irritation. However, these molecules which reflect/scatter UV can cause whitening 
of the skin. Therefore, metal oxides are now frequently processed as microfine or nanoparticles $(10-50 \mathrm{~nm})$. Nanoparticles reflect/scatter and absorb UVA and UVB, and they are transparent on the skin, thus enhancing the cosmetic acceptability of the product [51].

It was thought that the UV-filter acts as "artificial melanin" but most of sunscreen organic chemicals cannot dissipate the energy of the excited state as efficiently as melanin or DNA (Table.1) and, therefore, the penetration of sunscreen ingredients into the lower layers of skin increases the amount of ROS $[52,53]$.

Inorganic sunscreen agents (metal oxides) screen UVA/UVB radiation efficiently, but can also generate harmful reactive oxygen species and radicals when subjected to UVA/UVB radiation $[54,55]$.

DNA damage can be reduced by topical sunscreen which stays on the surface of the skin; it is important that the sunscreen blocks both UVA and UVB [56]. However, if sunscreen penetrates the epidermal barrier and gets into contact with living tissue, the DNA damage can be amplified many times, causing damage to living tissue even at very low concentrations (e.g. 10 $\mu \mathrm{mol} / \mathrm{L})$ [57-59].

Skin penetration of organic UV filters such as ethoxylated ethyl-4-aminobenzoate (PEG-25 PABA), benzophenone, benzophenon-3 (oxybenzon), salicylic compounds, octocrylene, octylmethoxycinnamate has been reported $[52,60,61]$. Skin penetration of metal nanoparticles also causes mistrust of sunscreen products usage [62].

In general, the penetration of rabbit skin $>$ rat $>$ pig $>$ monkey $>$ human, with the pig skin being about 4 times or more and the rat skin up to about 9 times more permeable than human skin for certain compounds [63]. Penetration can also vary depending on the bulk composition of the compound studied. In most safety testing experiments pretreated chemicals isolated from sunscreens are used, but incorporated sunscreen chemicals in cosmetic creams/lotions presented as oil-in-water $(\mathrm{O} /$ $\mathrm{W})$ or water-in-oil $(\mathrm{W} / \mathrm{O})$ emulsion enhance the penetration of these pretreated chemicals into the skin $[60,64]$. Also the formulation vehicle in which the sunscreen is presented to the skin has a significant effect on absorption into the skin [65]. Alcohol-based formulations appear to increase sunscreen absorption. In addition, some sunscreen chemicals may enhance the skin absorption of other sunscreens when applied in combination [66].

Some ingredients in sunscreens protect only against direct DNA damage, but increase indirect DNA damage $[59,58,67]$. It is assumed that this causes an increase in melanoma cases found repeatedly in sunscreen users compared to non-users [68-71]. Other studies have found decreased melanoma risk with increased sunscreen use [72-74]. Discrepancies in reported claims may be caused by differences in the frequency of use, quantities used and the sun protection factor (SPF) of sunscreens. Sunscreens used before likely protected only against UVB, whereas currently sunscreens often have both UVA and UVB protection. Furthermore, although most studies include skin phototype and sun sensitivity, results were not statistically adjusted to account for the sun sensitivity of study participants (i.e. individuals with increased risk for sunburn are more likely to develop melanoma, but they are also most likely to use sunscreens [51].

\section{Photosensitive drugs}

Drug-induced photosensitivity may occur in a variety of ways. Most reactions are generally classified as either phototoxic or photoallergic. Phototoxic reactions are chemically-induced reactions when the drug causes a deeper penetration of UVA light followed by cellular damage. This reaction can be seen with initial exposure to a drug and is perhaps dose-related [75,76]. Photosensitization reactions of drugs lead to the formation of ROS and cause indirect DNA damage [77-80]. It may occur due to topical or systemic drugs (Table 2) [81].

\section{Cancer risk of cosmetic ingredients}

Cosmetic ingredients are absorbed through the skin. Some chemicals may penetrate the skin in significant amounts, especially when left on the skin for long

Table 1 Dissipation of photon energy by natural and synthetic organic chromophores

\begin{tabular}{lll}
\hline UV-absorber & Other names & $\begin{array}{l}\text { Percentage of molecules that dissipate the } \\
\text { photon energy }\end{array}$ \\
\hline DNA & & $>99.9 \%$ \\
\hline natural melanin & $>99.9 \%$ \\
\hline $\begin{array}{l}\text { 2-ethylhexyl 4-(dimethylamino) } \\
\text { benzoate }\end{array}$ & Padimate-O, octyldimethyl PABA, OD-PABA \\
\hline 4-Methylbenzylidene camphor & $(4-M B C),(M B C)$, Parsol 5000, Eusolex 6300 & $10 \%$ \\
\hline Menthyl anthranilate & $(M A)$, Methyl-2-aminobenzoate, meradimate & $30 \%$ \\
\hline Ethylhexyl methoxycinnamate & $(2-E H M C),(E H M C), E M C$, Octyl methoxycinnamate, OMC, & $60 \%$ \\
\hline & Eusolex 2292, Parsol & $81 \%$ \\
\hline
\end{tabular}


Table 2 Some drugs associated with photosensitivity reactions

\begin{tabular}{ll}
\hline Frequent & Less frequent \\
\hline Amiodarone & $\begin{array}{l}\text { Antidepressants (tricylic, } \\
\text { MAOls) }\end{array}$ \\
\hline NSAIDs & Antifungals \\
\hline $\begin{array}{l}\text { Phenothiazines (particularly } \\
\text { chlorpromazine) }\end{array}$ & Antimalarials \\
\hline Retinoids & Benzodiazepines \\
\hline Sulfonamides & Beta-blockers \\
\hline Tetracyclines (particularly \\
demeclocycline) & Carbamazepine \\
\hline Thiazides & Griseofulvin \\
\hline & Oral contraceptives \\
\hline & Quinine \\
\hline & Quinolones \\
\hline & Retinoids \\
\hline & St John's Wort \\
\hline
\end{tabular}

periods, as in the case of facial makeup. Cancer risks from substances in cosmetic and personal care products have been reported (Table 3) [82].

Components of temporary tattoos and hair dye ingredients, namely para-aminophenol (PAP) and para-phenylenediamine (PPD), have been reported to be carcinogenic and transformed in human skin $[83,84]$. However, other studies suggest that consumer or professional exposure to hair dyes poses no carcinogenic or other human health risks [85]. Absorption spectra of these compounds that absorb also UVA /UVB light [86], and possible penetration of these ingredients from dyes, can cause UV-induced indirect DNA damage. According to members of Cosmetic Ingredient Review (CIR), many cosmetic ingredients are used without sufficient data to support safety, especially impurities, UV adsorption, photosensitization, and genotoxicity. Information about cosmetic ingredients such as benzoxiquine, melamine/ formaldehyde resin, oxyquinoline, oxyquinoline sulfate etc. should be verified (CIR, 1997, 2006) [87].

\section{Indoor environment}

Outdoor workers can get three to nine times as much solar UVR exposure as indoor workers $[88,89]$. Paradoxically, outdoor workers have a lower incidence of cutaneous malignant melanoma compared to indoor workers [90-92]. It is supposed that indoor solar UVA exposure, which causes mutations, depletes vitamin D3 in the skin [93]. In the early 20th century, due to life style changes, people tended to stay indoors during the day, which drastically decreased their daily amount of cutaneous vitamin D3. The UV barrier created by window glass separated UVB from UVA, so that the vitamin D making UVB was excluded from our indoor working environment. It is hypothesized that this unnatural UV environment, which existed for decades in buildings and cars, caused cutaneous malignant melanoma incidence to increase steadily about $20-30$ years later in the mid1930s. Increased UVA exposure and decreased cutaneous Vitamin D3 levels may be responsible for the increasing incidence of melanoma [94] (Fig. 2). Melanoma cells can convert vitamin D3 to the hormone, 1,25-dihydroxyvitamin D3, or calcitriol, which causes growth inhibition and apoptotic cell death in vitro and in vivo [94].

\section{Artificial UV lamps and ionizing radiation}

Lamps used for sun tanning emit wavelengths in the short end of the UVA range. Despite claims from the tanning industry, artificial tanning is not a safe or useful way to increase systemic vitamin D levels $[93,95]$. Many studies indicate a significantly increased risk of cutaneous melanoma subsequent to sunburn/sunlamp exposure, especially among individuals who are young, Caucasian, and female [96-98]. A European study showed that

Table 3 Cosmetic ingredients and cancer risk

\begin{tabular}{ll}
\hline Cosmetic substance & Risk \\
\hline DEA (diethanolamine) & can result in formation of carcinogenic nitrosamines \\
TEA (triethanolamine) & \\
\hline $\begin{array}{l}\text { Bronopol (2-bromo-2-nitropropane- } \\
\text { 1,3-diol) }\end{array}$ & may break down into formaldehyde and also cause the formation of nitrosamines \\
\hline 1,2-Dioxane in surfactants/detergents & contaminated with carcinogenic 1,4-dioxane \\
\hline $\begin{array}{l}\text { Artificial colours (as Blue 1 and } \\
\text { Green 3) }\end{array}$ & Carcinogenic \\
\hline Hair dyes & dark colours ingredients are carcinogenic \\
\hline Cosmetic lanolin & can be contaminated with carcinogenic pesticides such as DDT, dieldrin, and lindane, in addition to other \\
\hline Talc & Carcinogenic \\
\hline Silica & may be contaminated with carcinogenic crystalline quartz \\
\hline
\end{tabular}




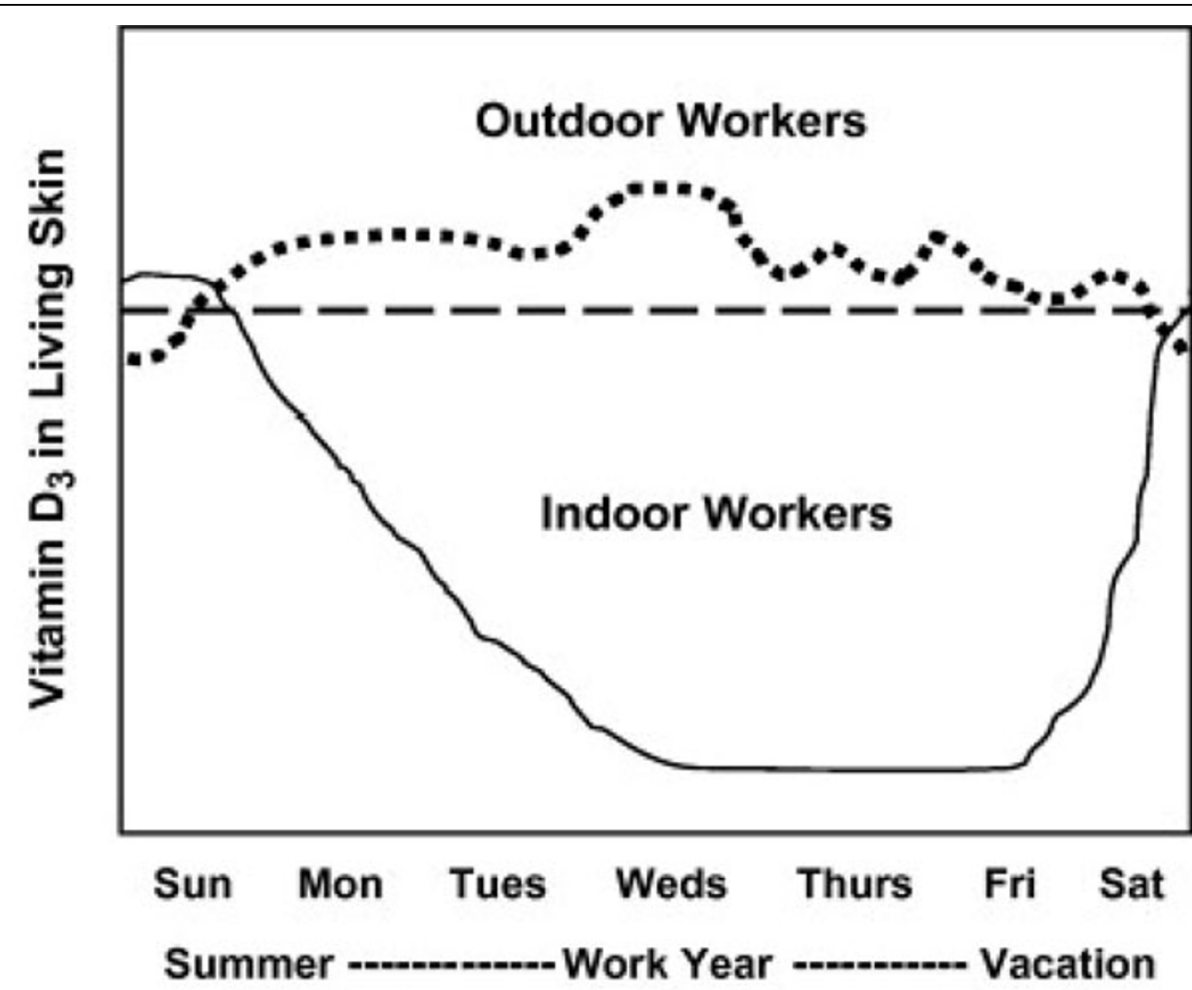

Figure 2 Cutaneous vitamin D3 The cutaneous vitamin D3 "roller coaster" that indoor workers experience during the workweek and workyear compared to outdoor workers. The curve for indoor workers (solid) rises on some weekends and during most vacations, while for outdoor workers (dotted) cutaneous vitamin D3 remains fairly constant and above the theoretical line for 'sufficient' cutaneous vitamin D3. (Godar D.E., 2009).

40 hours of sun bed use resulted in a $55 \%$ increased risk for melanoma [99].

More than 40 kinds of skin diseases such as sclerotic skin disease, vitiligo, atopic dermatitis, localized scleroderma etc. can be treated with artificial UVR by three types of phototherapy, namely, broadband UVB phototherapy, narrowband UVB phototherapy, and UVA phototherapy [100-103]. Phototherapy combined with chemicals such as oral methoxsalen (psoralen) in combination with UVA radiation (PUVA) provides a highly effective therapy for psoriasis and many other skin conditions such as vitiligo [104,105,102,101]. However, PUVA is carcinogenic and increases melanoma risk. This risk is greater in patients exposed to high doses of PUVA. It appears to be increasing with the passage of time, and should be considered in determining the risks and benefits of this therapy [106].

It is also suggested that people exposed to ionizing radiation, e.g., nuclear industry workers, subjects near nuclear test blasts, survivors of the atomic bombings of Japan, airline pilots and cabin attendants, recipients of medical radiation, and radiological technicians may be at increased risk of developing melanoma [107].
Sex hormones and stimulation of melanocytes

Normal and malignant pigment cells are known targets for many hormones. Besides alpha-melanocyte-stimulating hormones and the steroidal hormones estrogen, testosterone, and glucocorticoids, other factors produced by epidermal cells can stimulate melanocytes. Among these factors are the prostaglandins, vitamin D3, ETAF (epidermal cell-derived thymocyte activating factor), and interleukin-1 [108]. A relationship between the biological behaviour of melanoma and sex hormones action has been identified in several areas of research. These observations include different survival prognoses for females and males, the rarity of melanoma incidence in prepubescent children, pregnancy and effects of exogenous hormones [109-111]. Estrogen, estradiol and progesteron receptors have been observed in human melanomas [112-114] and, consequently, melanoma seems to be associated with female hormones.

\section{Sex}

The incidence of malignant melanoma is higher among females than males aged 15-30 years; after age 30, incidence is higher among males [115]. Generally older age 
and sex are associated with prognostically unfavourable primary cutaneous melanoma. Females have better prognosis than males but this difference disappears after age of 65. Younger patients have more favourable prognosis than older patients; this difference is more pronounced in women [116].

\section{Pregnancy and melanoma}

Melanoma is a major health care problem due to its growing incidence especially in the younger population. In some countries $30 \%$ to $35 \%$ of female melanoma patients are in their reproductive age [117] and, thus, melanoma can occur in pregnancy $([118,119]$. However, recent findings from more recent controlled studies suggest that the data do not support a more advanced stage, thicker tumors, increased metastases to lymph nodes, or a worsened survival of pregnant women diagnosed with localized cutaneous melanoma [120-124]. Pregnancy generally does not increase the subsequent risk of having melanoma and there is no increased risk of melanoma developing during pregnancy [125]. Patients expressing estradiol receptors in melanoma cells have been reported to have a better prognosis [114]. There is little evidence that significant changes in nevi occur during pregnancy [126-128].

\section{Exogenous hormones}

Recent multiple studies showed conflicting results on the association between oral contraceptive use and the development of cutaneous melanoma. While some studies suggest a cumulative dose-dependent increased risk of melanoma with use of estrogens [111], other reports demonstrate that hormone replacement therapy does not appear to enhance the risk for developing melanoma [120]. It is proposed, that estradiol therapy leads to a decrease of proliferation of melanoma cells and an increase in melanogenesis [114]. Endogenous estrogenic metabolite 2-methoxyestradiol was found to have potential preventive/therapeutic use for melanoma growth [129].

\section{Skin type and melanocytotic hyperpigmentation}

Malignant melanoma mainly afflicts people with white skin (the Caucasian population). Odd Ratio for influence by total nevi is $5.37,95 \% \mathrm{CI} 4.44$ to 6.36 . Particularly, dysplastic nevi confer much higher risks than most pigment characteristics [130].

Generally, melanoma and its precursor lesions nevi are melanocytotic hyperpigmentation caused by proliferation of active melanocytes. In multiple studies no clear evidence was found to associate melanocytes proliferation with steroid hormones regulation. On the other hand, increased melanin production by existing melanocytes (melanotic hyperpigmentation) is considered to be stimulated also by hormone regulation via melanocytic hormone receptors. Thus, the occurrence of hormone receptors in melanoma cells can be expected because melanoma cells can express pigment.

Melasma is an acquired hypermelanosis, occurring symmetrically on sun-exposed areas of the body. The pigmentation is due to overproduction of melanin by the pigment cells, melanocytes. Lesions are irregular light to dark brown macules and patches, usually involving the forehead, temples, upper lip, and cheeks. Asian and Hispanic females are most commonly affected [131-133]. Other authors found possible role of androgenic hormones in melasma [134]. Typically, melasma happens by increased melanin production by existing melanocytes (melanotic hyperpigmentation) [135]. No increase in the number of melanocytes in melasma areas was noted, but these cells are larger, more dendritic and show increased melanogenesis producing especially eumelanin [136].

During pregnancy, melanocytic activity increases causing hyperpigmentation as observed in the linea nigra (dark line running up the tummy) and the areola and nipple [137-139]. Occurrence of melasma (also known as chloasma) is also found to be associated with estrogen hormones [140,141]: increased expression of estrogen receptors in melasma-affected skin has been demonstrated [141]. Melasma has been reported in 50$70 \%$ of pregnant women [142-144] and in non pregnant women who are taking birth control pills [145]. It has been reported to exist only in $10 \%$ of men [146]. Sun exposure together with other exogenous factors (such as use of cosmetics and perfumes) are another risk factor for melasma [147]. It has been also thought to arise from endocrine disorders, genetic factors, other medications, nutritional deficiency and hepatic dysfunction [148].

\section{Family history (germline mutations)}

Approximately $5-10 \%$ of melanoma occurs in families with hereditary melanoma predisposition. About $40 \%$ of familial melanoma is associated with chromosome $9 p$ $[149,150]$. Worldwide, approximately $20-40 \%$ of kins with familial melanoma harbour germline mutations in the CDKN2A gene, located on chromosome 9p21, which encodes two different proteins, p16INK4 and p14ARF, both involved in regulation of cell cycle progression and induction of senescence. There are geographical variations in the incidence of CDKN2A mutations. The risk of melanoma in CDKN2A mutation carriers varies between populations and is higher in regions with high sun exposure and high incidence of melanoma in the general population [151]. Another melanoma susceptibility gene, CDK4, accounts for only small number of families with germ mutations on 
chromosome 12q14, encoding a cyclin dependent kinase which normally interacts with p16INK4A [151]. Relative risk to cutaneous melanoma depends on anatomic differences such as body site for skin, or hair colour. These differences could be attributed to gene variability [152].

\section{DNA polymorphisms/ somatic mutations}

A panel of polymorphisms that appears to confer lowto-moderate risk for melanoma has been assessed through functional and genome-wide association studies. Suggested associations between genetic polymorphisms and melanoma were extensively reviewed [153-157]. Vitamin D receptor (VDR) gene SNPs the FokI T allele was associated with increased melanoma risk (OR 1.42, 95\% confidence interval CI 1.06-1.91). In a meta-analysis the FokI $\mathrm{T}$ allele was associated with increased melanoma risk (OR 1.19, 95\%, CI 1.05-1.35), and the BsmI A allele was associated with reduced risk (OR 0.81, 95\%, CI 0.72-0.92). However, other study showed opposite results: a significant association between the BsmI VDR polymorphism and increased melanoma risk (OR, 1.30, 95\% CI, 1.11-1.53, the population attributable risk 9.2\%.). FokI polymorphism did not appear to be associated with such risk (OR, 1.09; 95\% CI, 0.99-1.21) $[157,158]$.

Mutations in the cell cycle gene CDKN2A (gene or mono-allelic loss at the locus) were connected with high risk of melanoma but results are not clear [159,160]. The oncogenic mutations in the B-RAF and N-RAS genes constitute the initiating somatic events followed by loss of a major check point gene mainly CDKN2A or in some cases p53 or PTEN [159-161].

The DNA repair process is important in protecting humans from cancer. Multiple DNA repair pathways are able to repair all kinds of DNA damage induced by exogenous and endogenous genotoxic agents, usually in an error-free manner. Recent reviews show links between the DNA repair pathways and cancer, particularly the association between nucleotide excision repair and melanoma development $(154,155,156)$. Nucleotide excision repair gene xeroderma pigmentosum variant (XPV) [154], the c.1783G, p.595V alleles were associated with melanoma (OR 1.86 CI 1.27-2.71, and OR 1.84 1.29-2.63 respectively). XPD/ERCC2 SNP rs1318, variant C allele was associated with slightly increased melanoma risk $(\mathrm{OR}=1.12,95 \%$ CI 1.03-1.21, population attributable risk $=9.6 \%)[156]$.

Some of the genetic variants in the DNA repair gene XRCC1 have also been associated with melanoma. Patients with variant genotype had better overall survival. MC1R variants were associated with susceptibility to basal cell carcinoma of skin and there is an interaction with host factors and the XRCC3 gene [162]. ASIP and TYR pigmentation variants are also associated with cutaneous melanoma and basal cell carcinoma. These results suggest that both nucleotide as well as base excision repair deficiency may contribute to the development of cutaneous melanoma. However, recent results show that the repair of major DNA damage caused by cancer drugs is efficient in metastatic melanoma [156]. This implies that in addition to genome association studies, more research on DNA repair and cell cycle regulation is needed.

\section{Conclusions}

Cutaneous melanoma is a complex, heterogeneous cancer that is increasing in incidence. Multiple studies have identified major host and environmental risk factors for melanoma. The predominant environmental risk factor is exposure to UV radiation. Geographical and individual factors such as sex, skin type (particularly dysplastic nevi) and life style - outdoor/indoor life, sunburn, vitamin $\mathrm{D}$ and antioxidant protections are considered to be risk factors. Additionally, exposure to other environmental factors such as sunscreen, photosensitising drugs, and exogenous hormones may also increase the risk of melanoma. Recently, the association between rare high risk susceptibility genes and common polymorphic genes and development of melanoma risk have been identified. However, more epidemiological as well as mechanistic studies are needed to understand the causal mechanisms of melanoma development.

\section{Acknowledgements}

The work has been funded by the EU FP6 coordination action HENVINET, contract no 037019

We are thankful to Sonja Grossberndt, Evy Sivesind and to the whole HENVINET team for an excellent support. We are thankful to William A. Lahoz from NILU for his proof reading.

This article has been published as part of Environmental Health Volume 11 Supplement 1, 2012: Approaching complexities in health and environment. The full contents of the supplement are available online at http://www ehjournal.net/supplements/11/S1

\section{Author details}

${ }^{1}$ Slovak Medical University, Bratislava, Slovakia. ${ }^{2}$ University of Venice, Venice, Italy. ${ }^{3} \mathrm{NILU}$ - Norwegian Institute for Air Research, Oslo, Norway. ${ }^{4}$ Slovak University of Technology, Bratislava, Slovak Republic.

\section{Authors' contributions}

$\mathrm{KV}$, DB, and MD conceived and designed the review, collected the data and drafted the manuscript. SL contributed to the conception of the review and its design. $A B$ is a HENVINET project coordinator and contributor to Framework development. All authors read and revised the final version of the manuscript.

\section{Competing interests}

None declared

Published: 28 June 2012

\section{References}

1. Situm M, Buljan M, Bulić SO, Simić D: The mechanisms of UV radiation in the development of malignant melanoma. Coll Antropol 2007, 1:13-16. 
2. Chang AE, Karnell LH, Menck HR: The National Cancer Data Base report on cutaneous and noncutaneous melanoma: a summary of 84,836 cases from the past decade. In Cancer. Volume 83. The American College of Surgeons Commission on Cancer and the American Cancer Society; 1998:1664-1678

3. Mehta RR, Bratescu L, Graves JM, Shilkaitis A, Green A, Mehta RG, Das Gupta TK: In vitro transformation of human congenital naevus to malignant melanoma. Melanoma Research 2002, 12:27-33.

4. Little JW: Melanoma: etiology, treatment, and dental implications. Gen Dent 2006, 54:61-66.

5. Habif TP: Clinical dermatology: a color guide to diagnosis and therapy. St. Louis: Mosby , 3rd 1996, 714-715.

6. Govindarajan B, Bai X, Cohen C, Zhong H, Kilroy S, Louis G, Moses M, Arbiser JL: Malignant Transformation of Melanocytes to Melanoma by Constitutive Activation of Mitogen-activated Protein Kinase Kinase (MAPKK) Signaling. The J Biol Chem 2003, 278:9790-9795.

7. Brenner S, Mashiah J: Malignant Melanoma: It Pays to Be a Woman. SKINmed 2003, 2:183-187.

8. Ivry GB, Ogle CA, Shim EK: Role of sun exposure in melanoma. Dermatol Surg 2006, 32:481-492.

9. MacKie RM: Long-term health risk to the skin of ultraviolet radiation. Prog Biophys Mol Biol 2006, 92:92-96.

10. Matsumu Y, Ananthaswamy HN: Toxic effects of ultraviolet radiation on the skin. Toxicol Appl Pharmacol 2004, 195:298-308.

11. Hölzle E, Hönigsmann H: UV-radiation-sources, wavelength, environment. J Dtsch Dermatol Ges 2005, 3(Suppl 2):3-10.

12. Madronich S, McKenzie RL, Björn LO, Caldwell MM: Changes in biologically active ultraviolet radiation reaching the Earth's surface. $J$ Photochem Photobiol B 1998, 46:5-19.

13. Garibyan L, Fisher DE: How sunlight causes melanoma. Curr Oncol Rep 2010, 12:319-326.

14. Afanas'ev IB: Signaling by reactive oxygen and nitrogen species in skin diseases. Curr Drug Metab 2010, 11:409-414.

15. Longstreth J, de Gruijl FR, Kripke ML, Abseck S, Arnold F, Slaper HI, Velders G, Takizawa Y, van der Leun JC: Health risks. J Photochem Photobiol B: Biol 1998, 46:20-39.

16. Peon J, Zewail AH: DNA/RNA nucleotides and nucleosides: direct measurement of excited-state lifetimes by femtosecond fluorescence up-conversion. Chem Phys Lett 2001, 348:255-262.

17. Young AR: Chromophores in human skin. Phys Med Biol 1997, 42:789-802.

18. Pecourt JML, Peon J, Kohler B: DNA Excited-State Dynamics: Ultrafast Internal Conversion and Vibrational Cooling in a Series of Nucleosides. J Am Chem Soc 2001, 123:10370-10378.

19. Pecourt JML, Peon J, Kohler B: Ultrafast internal conversion of electronically excited RNA and DNA nucleosides in water. J Am Chem Soc 2000, 122:9348-9349

20. Ito S: The IFPCS presidential lecture: a chemist's view of melanogenesis. Pigment Cell Res 2003, 16:230-236.

21. Jablonski NG, Chaplin G: The evolution of human skin coloration. J Hum Evol 2000, 39:57-106.

22. Meredith P, Riesz J: Radiative Relaxation Quantum Yields for Synthetic Eumelanin. Photochem Photobiol 2004, 79:211-216.

23. He YY, Huang JL, Sik RH, Liu J, Waalkes MP, Chignell CD: Expression profiling of human keratinocyte response to ultraviolet $A$ : implications in apoptosis. J Invest Dermatol 2004, 122:533-43.

24. Hoffmann K, Kaspar K, Altmeyer P, Gambichler T: UV transmission measurements of small skin specimens with special quartz cuvettes. Dermatology 2000, 201:307-311.

25. Eskandarpour M, Hashemi J, Kanter L: High Gene Mutation Rate May Contribute to Hereditary Skin Cancers. J Natl Cancer Inst 2003, 95:790.

26. Davies $\mathrm{H}$, Bignell GR, Cox C: Mutations of the BRAF gene in human cancer. Nature 2002, 417:949-954.

27. Parrish JA, Kurt F, Jaenicke R, Rox A: Erythema And Melanogenesis Action Spectra Of Normal Human Skin. Photochem Photobiol 1982, 36:187-191.

28. Li G, Ho VC, Trotter MJ, Horsman DE, Tron VA: Mutation In Metastatic Melanomas And Primary Melanomas From Sun-Exposed And SunProtected Sites. J Eur Acad Dermatol Venereol 1995, 4:48-53.

29. Goodsell DS: The Molecular Perspective: Ultraviolet Light and Pyrimidine Dimers. The Oncologist 2001, 6:298-299.

30. Friedberg EC, Walker GC, Siede W, Wood RD, Schultz RA, Ellenberger T: DNA repair and mutagenesis. ASM Press; 2nd 2006:1118:1120.
31. Whitmore SE, Potten CS, Chadwick CA, Strickland PT, Morison WL: Effect of photoreactivating light on UV radiation-induced alterations in human skin. Photodermatol Photoimmunol Photomed 2001, 17:213-217.

32. Matsunaga T, Hatakeyama Y, Ohta M, Mori T, Nikaido O: Establishment and characterization of a monoclonal-antibody recognising the Dewar isomers of (6-4) photoproducts. Photochem Photobiol 1993, 57:934-940.

33. Mitchell DL, Rosenstein BS: The use of specific radioimmunoassays to determine action spectra for the photolysis of (6-4) photoproducts. Photochem Photobiol 1987, 45:781-786.

34. Baier J, Maisch T, Maier M, Engel E, Landthaler M, Bäumler W: Singlet Oxygen Generation by UVA Light Exposure of Endogenous Photosensitizers. Biophys J 2006, 91:1452-1459.

35. Sohal RS, Weindruch R: Oxidative stress, caloric restriction, and aging. Science 1996, 273:59-63.

36. Hanson KM, Simon JD: Epidermal trans-urocanic acid and the UV-Ainduced photoaging of the skin. Proc Natl Acad Sci USA 1998, 95:10576-10578

37. Albro PW, Bilski P, Corbett JT, Schroeder JL, Chignell CF: Photochemical reactions and phototoxicity of sterols: novel self-perpetuating mechanisms for lipid photooxidation. Photochem Photobiol 1997, 66:316-325.

38. Wondrak GT, Roberts MJ, Jacobson MK, Jacobson EL: 3-Hydroxypyridine Chromophores Are Endogenous Sensitizers of Photooxidative Stress in Human Skin Cells. J Biol Chem 2004, 279:30009-30020.

39. Wenczl E, van der Schans GP, Roza L, Kolb RM, Timmerman AJ, Smit NPM, Pavel S, Schothorst AA: (Pheo)Melanin Photosensitizes UVA-Induced DNA Damage in Cultured Human Melanocytes. J Investig Dermatol 1998, 111:678-682.

40. Babu V, Joshi PC: Tryptophan as an endogenous photosensitizer to elicit harmful effects of ultraviolet B. Indian J Biochem Biophys 1992, 29:296-298.

41. Defedericis HC, Patrzyc HB, Rajecki MJ, Budzinski EE, Lijima H, Dawidzik JB, Evans MS, Greene KE, Box HC: Singlet oxygen-induced DNA damage. Radiat Res 2006, 165:445-451.

42. Mena S, Ortega A, Estrela JM: Oxidative stress in environmental-induced carcinogenesis. Mutat Res 2009, 674:36-44.

43. Ribeiro DT, Madzak C, Sarasin A, DI Mascio P, Sies H, Menck CFM: Singlet oxygen induced DNA damage and mutagenicity in a single-stranded SV40-based shuttle vector. Photochem Photobiol 1992, 55:39-45.

44. Jia L, Shafirovich V, Shapiro R, Geacintov NE, Broyde S: Spiroiminodihydantoin lesions derived from guanine oxidation: structures, energetics, and functional implications. Biochemistry 2005, 44(Suppl 16):6043-6051.

45. Magnus K: The Nordic profile of skin cancer incidence. A comparative epidemiological study of the three main types of skin cancer. Int $J$ Cancer 1991, 47:12-19.

46. Davies H, Bignell GR, Cox C: Mutations of the BRAF gene in human cancer. Nature 2002, 417:949-954

47. Dennis LK, Vanbeek MJ, Beane Freeman LE, Smith BJ, Dawson DV Coughlin JA: Sunburns and risk of cutaneous melanoma: does age matter? A comprehensive meta-analysis. Ann Epidemiol 2008, 18(Suppl 8):614-627.

48. Cripps DJ, Hegedus S: Protection factor of sunscreens to monochromatic radiation. Arch DenmatoL 1974, 7:202-204.

49. Rothman S, Rubin J: Sunburn and paraaminobenzoic acid. J Invest Dermatol 1942, 5:445-457.

50. Willis I, Kligmnan AM: Aminobenzoic acid and its esters: the quest for more effective sunscreens. ArchDermatoL 1970, 102:405-417.

51. Antoniou C, Kosmadaki MG, Stratigos AJ, Katsambas AD: Sunscreenswhat's important to know. J Eur Acad Dermatol Venereol 2008, 22:1110-1118.

52. Hanson KM, Gratton E, Bardeen CJ: Sunscreen enhancement of UVinduced reactive oxygen species in the skin. Free Radical Biol Med 2006, 41(Issue 8):1205-1212.

53. Cantrell A, McGarvey, David J: Sun Protection in Man. In Comprehensive Series in Photosciences. Volume 495. Elsevier; 2001:497-519.

54. Arsac F, Hisao H: DNA Damage Photoinduced by Titanium Dioxide in the Presence of Anionic Vesicles under UV Illumination: Influence of Sodium Chloride Concentration. Journal of Oleo Science 2007, 56:595-601.

55. Hidaka H, Kobayashi H, Koike T, Sato T, Serpone N: DNA Damage Photoinduced by Cosmetic Pigments and Sunscreen Agents under Solar 
Exposure and Artificial UV Illumination. Journal of Oleo Science 2006, 55:249-261.

56. Autier P: Perspectives in melanoma prevention: the case of sunbeds. Eur J Cancer 2004, 40:2367.

57. Armeni T, Damiani E, Battino M, Greci L, Principato G: Lack of in vitro protection by a common sunscreen ingredient on UVA-induced cytotoxicity in keratinocytes. Toxicol 2004, 203:165-178.

58. Knowland J, McKenzie EA, McHugh PJ, Cridland NA: Sunlight-induced mutagenicity of a common sunscreen ingredient [abstract]. FEBS Letters 1993, 324:5309-313.

59. Xu C, Green A, Parisi A, Parsons PG: Photosensitization of the Sunscreen Octyl p-Dimethylaminobenzoate b UVA in Human Melanocytes but not in Keratinocytes. Photochem Photobiol 2001, 73:600-604.

60. Couteau C, Perez Cullel N, Connan AE, Coiffard LM: Stripping method to quantify absorption of two sunscreens in human. Int J Pharm 2001, 222:153-157.

61. Simonsen L, Jørgensen A, Benfeldt E, Grotha L: Differentiated in vivo skin penetration of salicylic compounds in hairless rats measured by cutaneous microdialysis. Eur J Pharmaceut Sci 2004, 21:379-388.

62. Agren MS: Percutaneous absorption of zinc from zinc oxide applied topically to intact skin in man [abstract]. Dermatologica 1990, 180:536-39.

63. Magnusson BM, Kenneth A, Walters KA, Roberts MS: Veterinary drug delivery: potential for skin penetration enhancement. Adv Drug Deliv Rev 2001, 50:205-227.

64. Linn EE, Pohland RC, Byrd TK: Microemulsion for Intradermal Delivery Of Cetyl Alcohol and Octyl Dimethyl PABA. Drug Dev Ind Pharm 1990, 16:899-920.

65. Varvaresou A: Percutaneous absorption of organic sunscreens. J Cosmet Dermatol 2006, 5:53-57.

66. Benson HAE: Assessment and Clinical Implications of Absorption of Sunscreens Across Skin. Am J Clin Dermatol 2000, 1:217-224.

67. Damiani E, Greci L, Parsons R, Knowland J: Nitroxide radicals protect DNA from damage when illuminated in vitro in the presence of dibenzoylmethane and a common sunscreen ingredient. Free Radic Biol Med 1999, 26:809-816.

68. Garland C, Garland F, Gorham E: Could sunscreens increase melanoma risk? Am J Public Health 1992, 82:614-615.

69. Westerdahl J, Ingvar C, Masback A, Olsson H: Sunscreen use and malignant melanoma. Int J Cancer 2000, 87:145-150.

70. Weinstock MA: Do sunscreens increase or decrease melanoma risk: An epidemiologic evaluation. J Investig Dermatol Symp Proc 1999, 4:97-100.

71. Vainio H, Bianchini F: Cancer-preventive effects of sunscreens are uncertain. Scand J Work Environ Health 2000, 26:529-531.

72. Moloney FJ, Collins S, Murphy GM: Sunscreens: Safety, Efficacy and Appropriate Use. Am J Clin Dermatol 2002, 3:185-191.

73. Ródenas JM, Delgado-Rodríguez M, Herranz MT, Tercedor J, Serrano S: Sun exposure, pigmentary traits, and risk of cutaneous malignant melanoma: a case-control study in a Mediterranean population. Canc Causes Contr 1996, 7:275-283.

74. Espinosa Arranz J, Sanchez Hernandez JJ, Bravo Fernandez P, GonzalezBaron M, Zamora Auñon P, Espinosa Arranz E, Jalon Lopez JI, Ordoñez Gallego A: Cutaneous malignant melanoma and sun exposure in Spain [abstract]. Melanoma Res 1999, 9:s199-205.

75. Moore DE: Drug-induced cutaneous photosensitivity. Drug Saf 2002, 25:345-372.

76. Allen JE: Drug-induced photosensitivity. Clin Pharm 1993, 12:580-587.

77. Pandey R, Mehrotra S, Ray RS, Joshi PC, Hans RK: Evaluation of UVradiation induced singlet oxygen generation potential of selected drugs. Drug Chem Toxicol 2002, 25:215-225.

78. Xiaa Q, Yin JJ, Cherng SH, Wamer WG, Boudreau M, Howard PC, Fu PP: UVA photoirradiation of retinyl palmitate-Formation of singlet oxygen and superoxide, and their role in induction of lipid peroxidation. Toxicol Lett 2006, 163:30-43.

79. Iwamoto T, Hiraku Y, Okuda M, Kawanishi S: Mechanism of UVAdependent DNA Damage Induced by An Antitumor Drug Dacarbazine in Relation to its Photogenotoxicity. Pharmaceut Res 2008, 25:598-604.

80. O'Donovan P, Perrett CM, Zhang X, Montaner B, Xu Y-Z, Harwood CA, McGregor JM, Walker SL, Hanaoka F, Karran P: Azathioprine and UVA Light Generate Mutagenic Oxidative DNA Damage. Science 2005, 309:1871-1874.
81. Lee A, Thomson J: Adverse Drug Reactions. 2nd edtition. Pharmaceutical Press; 2006, 143-145.

82. Steinma D, Epstein S: The Safe Shopper's Bible. A Consumer's Guide to Nontoxic Household Products, Cosmetics, and Food. New York: MacMillan; 1995.

83. Nohynek GJ, Ducheb D, Garrigues A, Meunier P-A, Toutaina H, Leclaire J: Under the skin: Biotransformation of para-aminophenol and paraphenylenediamine in reconstructed human epidermis and human hepatocytes. Toxicol Lett 2005, 158:196-212.

84. Rojanapo W, Piangchai K, Anong T, Sopa Chutimataewin M, Tanyakaset M: Carcinogenicity of an oxidation product of p-phenylenediamine. Carcinogenesis 1986, 7:1997-2002.

85. Nohynek GJ, Fautz R, Benech-Kieffer F, Toutain H: Toxicity and human health risk of hair dyes. Food Chem Toxicol 2004, 42:517-543.

86. Motz-Schalck L, Lemaire J: Photochemical and thermal modifications of permanent hair dyes. J Photochem Photobiol Chem 2002, 147:225-223.

87. Andersen FA: Final Report on the Safety Assessment of Melamine/ Formaldehyde Resin. Int J Toxicol 1995, 14:373-385.

88. Godar DE: UV doses worldwide. Photochem. Photobiol 2005, 81(4):736-49.

89. Thieden E, Philipsen PA, Sandby-Møller J, Heydenreich J, Wulf HC: Proportion of lifetime UV dose received by children, teenagers and adults based on time-stamped personal dosimetry. J Invest Dermatol 2004, 123:1147-1150.

90. Lee JAH: Melanoma and exposure to sunlight. Epidemiol Rev 1982, 4:110-136.

91. Vagero D, Ringback G, Kiveranta H: Melanoma and other tumors of the skin among office, othe indoor, and outdoor workers in Sweden 19611979. Brit J Cancer 1986, 53:507-512.

92. Kennedy C, Bajdik CD, Willemze R, De Gruijl FR, Bouwes Bavinck JN: The influence of painful sunburns and lifetime sun exposure on the risk of actinic keratoses, seborrheic warts, melanocytic nevi, atypical nevi, and skin cancer. J Invest Dermatol 2003, 120:1087-1093.

93. Levine JA, Sorace M, Spencer J, Siegel DM: The indoor UV tanning industry: A review of skin cancer risk, health benefit claims, and regulation. J Am Acad Dermatol 2005, 53:1038-1044.

94. Godar DE, Robert J, Landry A, Lucas AD: Increased UVA exposures and decreased cutaneous Vitamin D3 levels may be responsible for the increasing incidence of melanoma. Med Hypotheses 2009, 72:434-443.

95. Weinstock MA, Fisher DE: Indoor ultraviolet tanning: what the data do and do not show regarding risk of melanoma and keratinocyte malignancies. J Natl Compr Canc Netw 2010, 8:867-873.

96. Gallagher RP, Spinelli JJ, Lee TK: Tanning beds, sunlamps, and risk of cutaneous malignant melanoma. Cancer Epidemiol Biomarkers Prev 2005, 14:562-566.

97. Heckman CJ, Coups EJ, Manne SL: Prevalence and correlates of indoor tanning among US adults. J Am Acad Dermatol 2008, 58:769-780.

98. Marshall Jessica: Beware the A-ray. The New Scientist Volume 2007, 194(Issue 2610):38-41

99. Autier P, Dore JF, Schifflers E, Cesarini JP, Bollaerts A, Koelmel KF, Gefeller O, Liabeuf A, Lejeune F, Lienard D: Melanoma and use of sunscreens: An EORTC case control study in Germany, Belgium and France. Int. J. Cancer 1995, 61:749-755.

100. Kroft EB, Berkhof NJ, van de Kerkhof PC, Gerritsen RM, de Jong EM: Ultraviolet A phototherapy for sclerotic skin diseases: a systematic review. J Am Acad Dermatol 2008, 59:1017-1030.

101. Gawkrodger DJ, Ormerod AD, Shaw L, Mauri-Sole I, Whitton ME, Watts MJ, Anstey AV, Ingham J, Young K: Guideline for the diagnosis and management of vitiligo. Br J Dermatol 2008, 159:1051-1076.

102. Morison WL: Phototherapy and photochemotherapy: an update. Semin Cutan Med Surg 1999, 18:297-306.

103. Wetzig T, Sticherling M, Simon J-C, Hegenbart U, Niederwieser D, Al-Ali HK: Medium dose long-wavelength ultraviolet A (UVA1) phototherapy for the treatment of acute and chronic graft-versus-host disease of the skin. Bone Marrow Transplant 2005, 35:515-519.

104. Lauharanta J: Photochemotherapy. Clin Dermatol 1997, 15:769-780.

105. Lowe NJ, Chizhevsky V, Gabriel H: Photo (chemo) therapy: general principles. Clin Dermatol 1997, 15:745-752.

106. Stern RS: The PUVA Follow up Study, The risk of melanoma in association with long-term exposure to PUVA. J Am Acad Dermatol 2001, 44:755-761. 
107. Fink CA, Bates MN: Melanoma and ionizing radiation: is there a causa relationship? Radiat Res 2005, 164:701-710.

108. Abdel-Malek ZA: Endocrine factors as effectors of integumental pigmentation. Dermatol Clin 1988, 6:175-183.

109. Scoggins CR, Merrick IR, Douglas S, Reintgen DS, Noyes RD, Goydos JS, Beitsch PD, Urist MM, Ariyan S, Sussman JJ, Edwards MJ, Chagpar AB, Martin RCG, Stromberg AJ, Hagendoorn L, McMasters KM: Sunbelt Melanoma Trial: Gender-Related Differences in Outcome for Melanoma Patients. Ann Surg 2006, 243:693-700.

110. Lange JR, Palis BE, Chang DC, Soong S-J, Balch CM: Melanoma in children and teenagers: An analysis of patients from the National Cancer Data Base. J Clin Oncol 2007, 25:1363-1368.

111. Koomen ER, Joosse1 A, Herings RMC, Casparie MK, Guchelaar HJ, Nijsten T: Estrogens, oral contraceptives and hormonal replacement therapy increase the incidence of cutaneous melanoma: a population-based case-control study. Ann Oncol 2009, 20:358-364.

112. McCarty KS Jr, Wortman J, Stower SS, Lugahn DB, McCarty KS Sr, Seigler HF: Sex steroid receptor analysis in human melanoma. Cancer 1980, 46:1463-1470

113. Im S, Lee ES, Kim W, On W, Kim J, Lee M, Kang WH: Donor Specific Response of Estrogen and Progesterone on Cultured Human Melanocytes. J Korean Med Sci 2002, 17:58-64.

114. Sarti M, Visconti MA, Castrucci AML: Biological activity and binding of estradiol to SK-Mel 23 human melanoma cells. Braz J Med Biol Res 2004, 37:901-905.

115. Zell JA, Cinar P, Mobasher M, Ziogas A, Meyskens FL Jr, Anton-Culver H: Survival for patients with invasive cutaneous melanoma among ethnic groups: the effects of socioeconomic status and treatment. $J$ Clin Oncol 2008, 26:66-75.

116. Konstantinos L, Leiter U, Meier F, Eigentler T, Metzler G, Moehrle M, Breuninger $H$, Garbe $C$ : Age and gender are significant independent predictors of survival in primary cutaneous melanoma. Cancer 2008, 112(No. 8):1795-1780.

117. Pavlidis N: Cancer and pregnancy. Ann Oncol 2000, 11:247-255

118. Pavlidis NA: Coexistence of pregnancy and malignancy. The Oncologist 2002, 7:279-287

119. Jemal A, Murray T, Samuels A, Ghafoor A, Ward E, Thun MJ: Cancer statistics, 2003. CA Cancer J Clin 2003, 53:5-26.

120. Driscoll MS, Grant-Kels JM: Melanoma and pregnancy. G Ital Dermatol Venereol 2008, 143:251-257.

121. O'Meara AT, Cress R, Xing G, Danielsen B, Smith LH: Malignant melanoma in pregnancy. A population-based evaluation. Cancer 2005, 103:1217-1226.

122. Lens MB, Rosdahl I, Ahlbom A, Farahmand BY, Synnerstad I, Boeryd B, Newton Bishop JA: Effect of Pregnancy on Survival in Women With Cutaneous Malignant Melanoma. Am J Clin Oncol 2004, 22( No 21):4369-4375.

123. Lens $M$, Bataille $V$ : Melanoma in relation to reproductive and hormonal factors in women: current review on controversial issues. Canc Causes Contr 2008, 19:437-442.

124. Silipo V, De Simone P, Mariani G, Buccini P, Ferrari A, Catricala C: Malignant melanoma and pregnancy. Melanoma Res 2006, 16:497-500.

125. Karagas MR, Zens MS, Stukel TA, Swerdlow AJ, Rosso S, Osterlind A, Mack T, Kirkpatrick C, Holly EA, Green A, Gallagher R, Elwood JM, Armstrong BK: Pregnancy history and incidence of melanoma in women: a pooled analysis. Canc Causes Contr 2006, 17:11-19.

126. Grin CM, Rojas Al, Grant-Kels JM: Does pregnancy alter melanocytic nevi? J Cutan Pathol 2001, 28:389-392.

127. Gunduz K, Koltan S, Sahin MT, Filiz E: Analysis of melanocytic naevi by dermoscopy during pregnancy. J Eur Acad Dermatol Venereol 2003 17:349-351.

128. Katz VL, Farmer RM, Dotters D: Focus on primary care: from nevus to neoplasm: myths of melanoma in pregnancy. Obstet Gynecol Surv 2002, 57:112-119.

129. Ghosh R, Ott AM, Seetharam D, Slaga T, Kumar AP, Addanki P: Cell cycle block and apoptosis induction in a human melanoma cell line following treatment with 2-methoxyoestradiol: therapeutic implications? Melanoma Res 2003, 13:119-127.

130. Chaudru V, Chompret A, Bressac-de Paillerets B, Spatz A, Avril MF, Demenais F: Influence of genes, nevi, and sun sensitivity on melanoma risk in a family sample unselected by family history and in melanomaprone families. J Natl Cancer Inst 2004, 96:785-795.

131. Victor FC, Gelber J, Rao B: Melasma: a review. J Cutan Med Surg 2004, 8:97-102.

132. Kang WH, Yoon KH, Lee ES, Kim J, Lee KB, Yim H, Sohn S, Im S: Melasma: histopathological characteristics in 56 Korean patients. $\mathrm{Br} J$ Dermatol 2002, 146:228-237.

133. Freitag FM, Cestari TF, Leopoldo LR, Paludo P, Boza JC: Effect of melasma on quality of life in a sample of women living in southern Brazil. J Eur Acad Dermatol Venereol 2007, 22:655-662.

134. Adalatkhan H, Amani F: The Correlation between melasma, ovarian cysts and androgenic hormones (a case control study). Res Biol Sci 2007, 2:593-596.

135. Cayce KA, McMichael AJ, Feldman SR: Hyperpigmentation: An Overview of the Common Afflictions. Dermatol Nurs 2004, 16:401-416.

136. Grimes PE, Yamada N, Bhawan J: Light microscopic, immunohistochemical, and ultrastructural alterations in patients with melasma. Am J Dermatopathol 2005, 27:96-101.

137. Amichaia B, Grunwald MH: Pigmentary demarcation lines of pregnancy. Eur J Obstet Gynecol Reprod Biol 2007, 131:239-240.

138. Barankin B, Silver SG, Carruthers A: The Skin in Pregnancy. J Cutan Med Surg 2002, 6:236-240.

139. Sceppa JA, Smith BL, Marghoob AA, Gottlieb GJ: Melanosis of the areola and nipple. J Am Acad Dermatol 2008, 59(Suppl 1):S33-S34.

140. McLeod SD, Ranson M, Mason RS: Effects of estrogens on human melanocytes in vitro. J Steroid Biochem Mol Biol 1994, 49:9-14.

141. Lieberman R, Moy L: Estrogen receptor expression in melasma: results from facial skin of affected patients. J Drugs Dermatol 2008, 7:463-465.

142. Elling SV, Powell FC: Physiological changes in the skin during pregnancy. Clin Dermatol 1997, 15:35-43.

143. Winton GB, Lewis CW: Dermatoses of pregnancy. J Am Acad Dermatol 1982, 6:977-998.

144. Black MM, Wilkinson JD: Skin diseases in pregnancy. In In Principles and Practice of Obstetrics and Perinatology. Philadelhia; John Wiley 1987:136-179.

145. Sanchez NP, Pathak MA, Sato S, Fitzpatrick TB, Sanchez JL, Mihm MC Jr: Melasma: a clinical, light microscopic, ultrastructural, and immunofluorescence study. J Am Acad Dermatol 1981, 4:698-710.

146. Jadotte YT, Schwartz RA: Melasma: insights and perspectives. Acta Dermatovenerol Croat 2010, 18:124-129.

147. Perez-Bernal A, Munoz-Perez MA, Camacho F: Management of Facial Hyperpigmentation. Disease Management. Am J Clin Derm 2000, $1: 261-268$

148. Fitzpatrick TB, Eisen AZ, Wolff K, Freedburg IM, Frank AK: Dermatology in General Medicine. Mcgraw-Hill; 1993, 996-997.

149. Kumar R, Smeds J, Lundh Rozell B, Hemminki K: Loss of heterozygosity at chromosome 9p21 (INK4-p14ARF locus): homozygous deletions and mutations in the p16 and p14ARF genes in sporadic primary melanomas. Melanoma Res 1999, 9:138-147.

150. Chaudru V, Chompret A, Bressac-de Paillerets B, Spatz A, Avril MF, Demenais $F$ : Influence of genes, nevi, and sun sensitivity on melanoma risk in a family sample unselected by family history and in melanomaprone families. J Natl Cancer Inst 2004, 96:785-795.

151. Hansson J: Familial cutaneous melanoma. Adv Exp Med Biol 2010, 685:134-145.

152. Bishop DT, Demenais F, Goldstein AM, Bergman W, Bishop JN, Bressac-de Paillerets B, Chompret A, Ghiorzo P, Gruis N, Hansson J, Harland M, Hayward N, Holland EA, Mann GJ, Mantelli M, Nancarrow D, Platz A, Tucker MA: Melanoma Genetics Consortium: Geographical variation in the penetrance of CDKN2A mutations for melanoma. J Natl Cancer Inst 2002, 94:894-903.

153. Udayakumar D, Tsao H: Melanoma genetics: an update on risk-associated genes. Hematol Oncol Clin North Am 2009, 23:415-429.

154. Di Lucca J, Guedj M, Lacapère JJ, Fargnoli MC, Bourillon A, Dieudé P, Dupin N, Wolkenstein P, Aegerter P, Saiag P, Descamps V, Lebbe C, BassetSeguin N, Peris K, Grandchamp B, Soufir N: Variants of the xeroderma pigmentosum variant gene $(\mathrm{POLH})$ are associated with melanoma risk. Eur J Cancer 2009, 45:3228-3236.

155. Mocellin S, Verdi D, Nitti D: DNA repair gene polymorphisms and risk of cutaneous melanoma: a systematic review and meta-analysis. Carcinogenesis 2009, 30:1735-43. 
156. Sarasin A, Dessen P: DNA repair pathways and human metastatic malignant melanoma. Curr Mol Med 2010, 10:413-418.

157. Mocellin S, Nitti D: Vitamin D receptor polymorphisms and the risk of cutaneous melanoma: a systematic review and meta-analysis. Cancer 2008, 113:2398-2407.

158. Randerson-Moor JA, Taylor JC, Elliott F, Chang YM, Beswick S, Kukalizch K, Affleck P, Leake S, Haynes S, Karpavicius B, Marsden J, Gerry E, Bale L, Bertram C, Field H, Barth JH, Silva ID, Swerdlow A, Kanetsky PA, Barrett JH, Bishop DT, Bishop JA: Vitamin D receptor gene polymorphisms, serum 25-hydroxyvitamin D levels, and melanoma: UK case-control comparisons and a meta-analysis of published VDR data. Eur $\mathrm{J}$ Cancer 2009, 45:3271-81.

159. Box NF, Duffy DL, Chen W, Stark M, Martin NG, Sturm RA, Hayward NK: MC1R Genotype modifies risk of mealnoma in families segregating CDKN2A mutations. Am J Hum Genet 2001, 69:765-773.

160. Landi MT, Bauer J, Pfeiffer RM, Elder DE, Hulley B, Minghetti P, Calista D, Kanetsky PA, Pinkel D, Bastian BC: MC1R Germline Variants Confer Risk for BRAF-Mutant Melanoma. Science 2006, 313:521-522.

161. Kumar R: BRAF Mutations in Metastatic Melanoma A Possible Association with Clinical Outcome. Clin Canc Res 2003, 9:3362-3368.

162. Scherer D, Bermejo IL, Rudnai P, Gurzau E, Koppova K, Hemminki K, Kumar R: MC1R variants associated susceptibility to basal cell carcinoma of skin: Interaction with host factors and XRCC3 polymorphism. Int J Cancer 2008, 122:1787-1793.

163. Cosmetic Ingredient Review (CIR) Expert Panel: Final Amended Report on the Safety Assessment of Oxyquinoline and Oxyquinoline Sulfate as Used in Cosmetics. Int J Toxicol 2006, 25:1-9.

164. Cosmetic Ingredient Review Expert Panel: Final report on the safety assessment of benzoxiquine. Int J Toxicol 1997, 16(Suppl 1):117-122.

165. The Montreal Protocol on Substances that Deplete the Ozone Layer: Secretariat for The Vienna Convention for the Protection of the Ozone Layer \& The Montreal Protocol on Substances that Deplete the Ozone Layer. 2000, 1-47.

doi:10.1186/1476-069X-11-S1-S12

Cite this article as: Volkovova et al: Associations between environmental factors and incidence of cutaneous melanoma. Review. Environmental Health 2012 11(Suppl 1):S12.

\section{Submit your next manuscript to BioMed Central and take full advantage of:}

- Convenient online submission

- Thorough peer review

- No space constraints or color figure charges

- Immediate publication on acceptance

- Inclusion in PubMed, CAS, Scopus and Google Scholar

- Research which is freely available for redistribution

Submit your manuscript at www.biomedcentral.com/submit
Biomed Central 